Teologia i Moralność, Volumen 15(2020), numer 2(28)

doi: 10.14746/tim.2020.28.2.07

ORCID: 0000-0001-7311-9780

KRZYSZTOF GRYZ

Uniwersytet Papieski Jana Pawła II w Krakowie

Wydział Teologiczny

\title{
Personalistyczne ujęcie chrześcijańskiej nauki moralnej w magisterium Soboru Watykańskiego II
}

W 2019 roku minęła sześćdziesiąta rocznica ogłoszenia przez papieża Jana XXIII zamiaru zwołania Soboru Watykańskiego II, który był bez wątpienia jednym z najdonioślejszych wydarzeń w życiu Kościoła XX wieku. Wydarzenie to stało się wielkim darem dla Kościoła, ale zarazem trudnym - jak się nieraz okaże - wyzwaniem, które wciąż jest podejmowane i które ciągle domaga się głębokiej i autentycznej, czyli zgodnej z wolą i intencją samego Soboru, interpretacji. Sobór postawił przed sobą zasadnicze zadanie podjęcia refleksji nad swoją własną tożsamością, a także nad stosunkiem Kościoła do świata, który przeżywając dynamiczne przemiany, stawiał wobec niego wielorakie wyzwania. W tym kontekście Sobór sformułował swoje nauczanie moralne, które zostało skoncentrowane na godności osoby ludzkiej.

Celem artykułu jest syntetycznie przedstawienie moralnego nauczania Soboru zarówno od strony metodologicznego ujęcia, jak też od strony merytorycznej zawartości.

\section{Zwolanie i przebieg Soboru}

Kiedy po śmierci Piusa XII wybrano 28 października 1958 roku na Urząd Piotrowy siedemdziesięciosiedmioletniego kard. Angela Giuseppe Roncallego, który przybrał imię Jana XXIII, wszyscy byli przekonani, że będzie to pontyfikat przejściowy. Jakież było jednak zaskoczenie, kiedy po kilku miesiącach urzędowania, 25 stycznia 1959 roku, w bazylice św. Pawła nowy papież zapowiedział wobec kolegium kardynałów zwołanie synodu diecezji rzymskiej, ale także soboru powszechnego (por. Jan XXIII 1959, 65-69). 
Idea zwołania soboru pojawiała się już wcześniej w różnych kręgach $\mathrm{Ku}$ rii Rzymskiej, jak również była przedstawiana przez kolejnych papieży. Poprzedni sobór, Watykański I, został przez Piusa IX bezterminowo zawieszony (sine die) 20 października 1870 roku (por. Pius IX 1870, 65-67) ze względu na wybuch wojny francusko-pruskiej, a później zajęcie Rzymu przez Królestwo Włoch, wobec czego papież uznał, że wznowienie prac soborowych jest niemożliwe. Pozostało jednak kilkadziesiąt projektów do przedyskutowania, w tym konstytucja o Kościele (De Ecclesia). Następcy Piusa IX rozważali wznowienie prac soborowych, a Pius XI w encyklice Ubi arcano (por. Pius XI 1922, 673-700) wprost ten zamiar wyraził. Również Pius XII nosił się z zamiarem zwołania soboru, który miałby jasno wystąpić przeciwko niektórym błędom epoki, i nawet podjął pewne kroki w tym kierunku, jednak ostatecznie projekt zaniechano. $Z$ drugiej strony niektórzy teologowie sądzili, że sobór nie jest już potrzebny, skoro po ogłoszeniu dogmatu o nieomylności papieża może on sam ustalić to, co uzna za stosowne (por. Forget 1906, kol. 669).

Głównym celem nowego soboru - jak to określił Jan XXIII - miało być zmodyfikowanie (aggiornamento) Kodeksu prawa kanonicznego, jednak to, co miało odnosić się zasadniczo do dyscypliny kościelnej, stało się procesem głębokich przemian w Kościele, a pojęcie aggiornamento ('aktualizowanie', 'wprowadzanie zmian', 'modernizowanie') stało się sztandarowym hasłem Soboru. Oficjalną zapowiedź zwołania Soboru wyraził papież w encyklice $A d$ Petri Cathedram, opublikowanej w czerwcu 1959 roku (por. Jan XXIII 1959b, 497-531), stwierdzając, że jego celem będzie ,poruszenie wielkich problemów życia religijnego, a zwłaszcza promocja rozwoju Kościoła katolickiego, odnowienie zwyczajów ludu Bożego i dostosowanie do potrzeb naszych czasów praw, które kierują dyscypliną kościelną" (Jan XXIII 1959b, III).

W maju tego samego roku powołano Komisję Przedprzygotowawczą (Commissio antepreparatoria), której przewodniczył sekretarz stanu kard. Domenico Tardini. Rozesłała ona prośby do biskupów, przełożonych zakonnych oraz wydziałów teologii i prawa kanonicznego, aby przesłali swoje sugestie na temat problematyki, która powinna być podjęta, co było nowością w przygotowywaniu prac soborowych. Dotychczas bowiem grono przygotowujących obrady soborowe liczyło kilkadziesiąt osób, najczęściej pracowników Kurii Rzymskiej. Nadeszło 2099 odpowiedzi (z Polski było ich 42), ale w większości nie były one zbyt inspirujące. Rok później, 5 czerwca 1960 roku, papież powołał dziesięć komisji przygotowawczych, które odpowiadały korpusowi kongregacji rzymskich, co zapowiadało nieco konformistyczne podejście, ale także dwa sekretariaty (do spraw prasy i widowisk oraz jedności chrześcijan), co było nowością i znakiem otwarcia na nowe czasy i problemy. Ich pracę koordynowała Komisja Centralna, której przewodniczył papież, a jej sekretarzem był abp Pericles Felici (jej członkiem był także kard. Stefan Wyszyń- 
ski). Krótko przed rozpoczęciem Soboru komisje wysłały pierwszych siedem projektów konstytucji ${ }^{1}$, aby ojcowie mogli się z nimi zapoznać. Niektórym się wydawało, że projekty, przygotowane przez specjalistów rzymskich, będą szybko poddane pod głosowanie, a sam Sobór może zakończyć się po kilku tygodniach. Jednak projekty te nie zostały dobrze przyjęte, zgłaszano wiele uwag, a nawet postulowano, aby poddać je gruntownej rewizji. $Z$ takimi propozycjami wystąpili między innymi belgijski kard. Léon-Joseph Suenens oraz kard. Joseph Frings z Kolonii (po konsultacji z młodym wówczas prof. J. Ratzingerem, por. Ratzinger 2016, s. 211-252; 507-561). Było to zapowiedzią zupełnej reorientacji wszystkich prac soborowych i ostatecznych owoców, które one przyniosły.

Uroczysta inauguracja Soboru miała miejsce w bazylice św. Piotra 11 października 1962 roku w obecności 2540 ojców, a Jan XXIII w wygłoszonym przemówieniu nakreślił jego zasadnicze kierunki. Papież stwierdził, że zadaniem Soboru jest przekazanie nieskażonej i pełnej doktryny, bez jej umniejszania czy zniekształcenia, ale zarazem wyjście naprzeciw wyzwaniom naszych czasów. Dlatego celem Soboru nie jest jedynie przedyskutowanie takiego czy innego tematu fundamentalnej doktryny Kościoła - „do tego nie jest potrzebny Sobór” - jak napisał papież. Sobór powinien mieć charakter bardziej duszpasterski i raczej pokazywać wartość doktryny chrześcijańskiej niż ponawiać potępienia. Papież przyznał, że w przeszłości Kościół wielokrotnie sprzeciwiał się błędnym naukom i surowo je potępiał, natomiast ,w obecnych czasach Oblubienica Chrystusa woli używać lekarstwa miłosierdzia bardziej niż surowości" (Jan XXIII 1962, 792). I dalej stwierdził, że „duch chrześcijański i katolicki na całym świecie oczekuje kroku naprzód w stronę pogłębienia doktrynalnego i kształtowania sumień, takiego, który lepiej i wierniej odpowiadałby prawdziwej doktrynie, która powinna być studiowana i wykładana przy pomocy metod badawczych i słownych formuł właściwych dla współczesnej myśli” (Jan XXIII 1962, 791).

Między tymi dwoma biegunami, z jednej strony nieskażonej wierności doktrynie, z drugiej zaś otwartości na współczesny świat, będą się toczyć wszystkie debaty w trakcie trwania Soboru. Dały się one zauważyć już na etapie przygotowawczym, a później w trakcie redagowania dokumentów. Sprawozdania i opinie medialne, które po raz pierwszy z taką uwagą i bliskością śledziły obrady, opisywały te dyskusje w ramach politycznych kategorii tradycjonalistów lub progresistów. Ówczesny profesor Joseph Ratzinger wspomina, że w środowisku niemieckich teologów, ale też wiernych, dawało się odczuć atmosferę wzrastającego napięcia. „Coraz częściej miało się wrażenie - pisze Ratzinger - że w Kościele nie ma nic stałego, że wszystko podlega rewizji.

${ }^{1}$ Wśród nich były także te odnoszące się do kwestii moralnych: De ordine morali christiano i De castitate, matrimonio, familia et virginitate. 
Coraz częściej Sobór wydawał się wielkim parlamentem, który może wszystko zmienić i kształtować na swój sposób. Całkiem wyraźnie dało się odczuć wzrastającą niechęć do Rzymu i Kurii, postrzeganych jako wrogów wszelkiej nowości i postępu" (Ratzinger 2005, 113-114).

W trakcie trwania Soboru odbyły się cztery sesje, z których każda trwała od dwóch do trzech miesięcy, a zwoływane były każdej jesieni od 1962 do 1965 roku (obrady trwały w sumie 1154 dni), podczas których miało miejsce 168 posiedzeń plenarnych, w których łącznie brało udział 3058 ojców soborowych $^{2}$, w tym 59 z Polski (dla porównania Sobór Watykański I zgromadził 764 ojców; por. Acta et Documenta 1960-1995; Storia del concilio 1995-1999; Alberigo 2005; Atlas historyczny Soboru 2015). Uchwalono cztery konstytucje, dziewięć dekretów i trzy deklaracje. Zdaniem Ratzingera, to one są prawdziwym dziedzictwem Soboru. „Staranna i gruntowna ich interpretacja chroni przed obiema skrajnościami i rzeczywiście otwiera drogę, która ma przed sobą długą przyszłość" (Ratzinger 1997, 64).

$\mathrm{Na}$ zakończenie Soboru ojcowie dokonali dwu znamiennych i symbolicznych aktów. Pierwszym było ogłoszenie 7 grudnia 1965 roku reformy Świętego Oficjum, które odtąd miało stanowić Świętą Kongregację Nauki Wiary (por. Paweł VI 1965, 952-955), urząd, który w nowy sposób, zgodnie z duchem soborowym, ma się troszczyć o pielęgnację wiary i jej głoszenie (w związku z tym zlikwidowano także Indeks Ksiąg Zakazanych). Drugim aktem było uroczyste zniesienie ekskomunik między Rzymem i Konstantynopolem (7 grudnia 1965) jako szczególny znak ekumenicznego ducha, którym Kościół chce się kierować wobec braci odłączonych, ale także jako wyraz postawy dialogu i otwartości wobec wszystkich szczerze poszukujących prawdy.

Uroczystość zamknięcia Soboru odbyła się 8 grudnia 1965 roku na placu św. Piotra mszą św. odprawianą przez Pawła VI, po której papież przekazał orędzie Soboru dla siedmiu wybranych grup społecznych: rządzących, uczonych, artystów, kobiet, robotników, ubogich i chorych oraz młodzieży.

\section{Charakterystyka Magisterium Soborowego}

We wstępie do polskiego wydania dokumentów soborowych bp Karol Wojtyła dokonał próby uporządkowania całego dorobku Vaticanum II i jego

\footnotetext{
${ }^{2}$ W Soborze, zgodnie z Kodeksem z 1917 r. kan. 223 §1, uczestniczyli: kardynałowie, patriarchowie, prymasi, arcybiskupi, biskupi diecezjalni i tytularni, opaci, prałaci tytularni oraz przełożeni wspólnot zakonnych, a Jan XXIII dołączył do nich także prefektów apostolskich, nawet jeśli nie byli biskupami. Najmłodszy biskup miał 34 lata, najstarszy zaś 100 lat.

${ }^{3}$ Wspólna deklaracja Pawła VI i patriarchy Atenagorasa o zdjęciu anatem z 1054 roku: Paweł VIa 1965, 40-41.
} 
syntetycznej charakterystyki ${ }^{4}$. Mimo iż na temat Soboru i jego nauczania powstało wiele opracowań, zatrzymamy się na tekście Wojtyły nie tylko z uwagi na jego przenikliwość, ale także dlatego, że najpierw jako biskup w swojej diecezji w Krakowie, a w przyszłości jako papież, był niestrudzonym realizatorem autentycznego nauczania soborowego ${ }^{5}$.

Najpierw biskup Wojtyła przedstawia stronę metodologiczną powstawania dokumentów. Ich chronologia miała swoje uzasadnienie zarówno w czynnikach zewnętrznych, takich jak jakość przygotowanej propozycji (schematu) czy też ilość czasu poświęconego na refleksję i dyskusję nad nim, ale także od czynnika wewnętrznego, jakim było wspólne dojrzewanie ojców soborowych do prawdy. Ujawniała się ona stopniowo w trakcie refleksji, na którą składały się różne zgłaszane propozycje. Do każdej z nich Komisja Centralna się ustosunkowywała, wyjaśniając, dlaczego ją uwzględnia lub też dlaczego nie. „Pod tym względem - pisze Wojtyła - praca Soboru była niezmiernie cennym świadectwem poszanowania każdej myśli" (Wojtyła 1967, 12).

Od strony merytorycznej dokumenty można uporządkować według rozróżnienia, które jeszcze przed rozpoczęciem Soboru zaproponował kard. Léon-Joseph Suenens: Ecclesia ad intra - Ecclesia ad extra. Najpierw Kościół próbował odpowiedzieć na pytanie, co myśli sam o sobie: Ecclesia quid dicis de te ipsa? Drugim kierunkiem refleksji Soboru była odpowiedź na szereg pytań, które stawia sobie współczesna ludzkość, a przed którymi staje także Kościół, który jest odpowiedzialny za swoje dzieci, a także za wszystkich innych, którzy są wezwani przez Boga do życia wiecznego. Takie podejście znajduje również odzwierciedlenie w encyklice Ecclesiam suam (6 sierpnia 1964) Pawła VI, który przejął po śmierci Jana XXIII zadanie kontynuacji Soboru.

Formuła Ecclesia ad intra - Ecclesia ad extra dobrze oddawała - twierdzi Wojtyła - głęboko ekumeniczny charakter Soboru, wyraża się w niej $\mathrm{z}$ jednej strony skupienie na swej istocie, $\mathrm{z}$ drugiej poszerzenie $\mathrm{i}$ otwarcie nie tylko na braci odłączonych, ale na szeroko rozumiany świat, co w niczym nie umniejsza natury i powołania Kościoła. „Kościół, chociaż wychodzi na «zewnątrz» siebie, to przecież nie odchodzi od swej własnej istoty. Wstępuje bowiem w wielkie dzieła Boże, nie tylko w dzieło Stworzenia, ale także

4 Polskie wydanie dokumentów przygotowane przez wydawnictwo Pallottinum: Sobór Watykański II, Konstytucje, dekrety, deklaracje (Poznań 1967), zaś nowe tłumaczenie ukazało się w tym samym wydawnictwie w 2002 roku. Pomocnym narzędziem do studiowania tekstów soborowych jest Synopsa tekstów Soboru Watykańskiego II, red. T. Bielski (Poznań-Warszawa 1970).

${ }^{5}$ Papież mówił o tym już w trakcie swojego pierwszego orędzia „Urbi et Orbi” następnego dnia po wyborze na Stolicę Piotrową. Przedstawiając zasadnicze linie swojego pontyfikatu, rozpoczął od podkreślenia znaczenia Soboru Watykańskiego II dla życia Kościoła: „Przede wszystkim chcemy przypomnieć o trwałym znaczeniu Powszechnego Soboru Watykańskiego II oraz przyjmujemy jako wyraźny obowiązek gorliwe wprowadzanie go w życie. [...] będziemy to czynić w sposób roztropny i równocześnie zachęcający" (Jan Paweł II 1978, 2). 
w dzieło Odkupienia w jego pełnym zasięgu" (Wojtyła 1967, 13), wszyscy bowiem zostali odkupieni przez Chrystusa. Z tej także perspektywy można mówić w najgłębszym sensie o duszpasterskim charakterze Soboru, nie tylko ze względu na bardziej praktyczne niż doktrynalne jego podejście. Karol Wojtyła podkreśla, że duszpasterskość Kościoła rodzi się z jego samoświadomości, z prawdy o tym, kim jest on sam; bez tego zrozumienia, które polega ostatecznie na wierze w Kościół, duszpasterstwo, czyli dialog ze światem, może przybrać niewłaściwe formy. Wiele późniejszych interpretacji nauki soborowej, które były kontrowersyjne, a nawet błędne, było wynikiem zapoznania tej integralnej relacji.

Refleksja Soboru w aspekcie Ecclesia ad intra wyraziła się przede wszystkim w takich fundamentalnych dokumentach, jak konstytucje: o Kościele Lumen gentium (21 listopada 1964), uważanej za podstawowy dokument Soboru, o objawieniu Bożym Dei verbum (18 listopada 1965) i o liturgii Sacrosanctum Concilium (4 grudnia 1963) - którą uchwalono jako pierwszą ${ }^{6} . \mathrm{Z}$ ich treści wyrastają niejako pozostałe dokumenty dotyczące życia Kościoła i posłannictwa każdego z jego członków ${ }^{7}$. W aspekcie refleksji nad Kościołem ad extra pierwszym wymiarem jest ekumenizm ${ }^{8}$, ale Sobór rozszerzył perspektywę dialogu na cały świat, czego szczególnym świadectwem jest konstytucja duszpasterska o Kościele w świecie współczesnym Gaudium et spes (7 grudnia 1965), która jest traktowana jako swego rodzaju odpowiednik konstytucji o Kościele Lumen gentium.

To, co jest charakterystyczne dla tej Konstytucji, to fakt, że jej przedmiotem są nie tyle same problemy współczesnego świata, ile rzeczywistość osoby, która zarazem jest twórcą złożonej sytuacji współczesnego świata, jak

${ }^{6}$ Symbolicznym znakiem wprowadzenia postulowanych w niej reform była msza święta sprawowana 7 marca 1965 r. przez Pawła VI w jednej z rzymskich parafii w odnowionym rycie: w języku włoskim i przy ołtarzu zwróconym w stronę wiernych.

${ }^{7}$ Układają się one wokół struktury zawartej w układzie treści konstytucji Lumen gentium. Należą do nich dekret o pasterskich zadaniach biskupów w Kościele Christus Dominus (28 października 1965), Dekret o posłudze i życiu kapłanów Presbyterorum ordinis (7 grudnia 1965) i korespondujący z nim Dekret o formacji kapłańskiej Optatam totius (28 października 1965), Dekret o przystosowanej odnowie życia zakonnego Perfectae caritatis (28 października 1965) czy wreszcie Dekret o apostolstwie świeckich Apostolicam actuositatem (18 listopada 1965). Dopełniają je, jeśli chodzi o apostolskie posłannictwo Kościoła, Dekret o środkach społecznego przekazywania myśli Inter mirifica (4 grudnia 1963) oraz Deklaracja o wychowaniu chrześcijańskim Gravissimum educationis (28 października 1965).

${ }^{8}$ Zagadnienie to poruszają przede wszystkim dekrety o Kościołach wschodnich Orientalium Ecclesiarum (21 listopada 1964) i o ekumenizmie Unitatis redintegratio (21 listopada 1964) oraz w poszerzonej wizji, jaką kierował się Sobór, Dekret o działalności misyjnej Kościoła Ad gentes divinitus (7 grudnia 1965), bardzo doniosła Deklaracja o stosunku Kościoła do religii niechrześcijańskich Nostra aetate (28 października 1965) oraz Deklaracja o wolności religijnej Dignitatis humanae (7 grudnia 1965), która dotyka samej podstawy ekumenizmu i dialogu. 
też sama doświadcza tych problemów, które są w nim obecne. Postrzeganie całej rzeczywistości przez pryzmat osoby jest „,szczególną jakby wypadkową współczesności i potwierdzeniem «współczesnego», tj. zakrojonego na miarę naszych czasów myślenia Soboru" (Wojtyła 1967, 20). Cały układ i treść Gaudium et spes koncentrują się wokół zagadnienia osoby, a czyni to dokument w dwojaki sposób. Najpierw dokonując opisu socjologicznego sytuacji, w jakiej znajduje się współczesny człowiek, po wtóre, dokonując analizy o charakterze normatywnym. Taki sposób prezentacji sprawia, że nabiera ona wymiaru etycznego. W analizie tej Sobór odwołuje się do zasad prawa naturalnego, które są szczególnie ważne we współczesnym kontekście, odnoszą się bowiem do problemów, które dotyczą wszystkich ludzi, nie tylko wierzących. Prawo naturalne wydaje się właściwym do tego narzędziem, ponieważ łączy w sobie powszechną świadomość moralną rozumnego człowieka z zasadniczą treścią przekazu ewangelicznego: ,prawo natury jest bowiem prawem rozumu potwierdzonym w Ewangelii" (Wojtyła 1967, 21). Orędzie Kościoła skonstruowane w taki sposób nabiera wymiaru uniwersalnego, jest skierowane do wszystkich ludzi niezależnie od ich wyznania czy kultury, w której żyją, jest rzeczywistą misją ad extra Kościoła. „Dziedzina moralności międzyludzkiej, społecznej, międzynarodowej jest tą właśnie dziedziną - pisze Wojtyła - w której Kościół jako głosiciel Ewangelii najszerzej wychodzi ad extra, tzn. znajduje najszerszą płaszczyznę dialogu i porozumienia z całą ludzkością" (Wojtyła 1967, 21).

Skoncentrowanie swojego nauczania wokół centralnego tematu, jakim jest osoba ludzka, nie oznacza, że Kościół zapoznaje tym samym sprawy społeczne, przeciwnie, stara się odsłonić ich najbardziej fundamentalne treści i znaczenie, podstawą bowiem każdej wspólnoty jest osoba. Dlatego właśnie jest ona tą szczególną wartością, według której należy kształtować postępowanie we wszystkich dziedzinach i wymiarach życia współczesnego świata. Takie też ujęcie sprawia, że Kościół wpisuje się w nurt personalistycznego myślenia etycznego i moralnego, charakterystycznego dla czasów współczesnych. Dodajmy, że w ten sposób Kościół otwiera się także na drugi wielki nurt myśli współczesnej, jakim jest egzystencjalizm, czyli refleksja nad fundamentalnymi treściami ludzkiej egzystencji w historii, odkrywając ich najgłębszy sens we właściwym sobie wymiarze soteriologicznym i eschatologicznym.

Jednocześnie to personalistyczne spojrzenie na sprawy całej ludzkości, które stanowi treść jego istnienia ad extra, pozwala Kościołowi na odniesienie do spraw należących do przestrzeni jego wewnętrznego życia - ad intra. W centrum życia Kościoła stoi bowiem człowiek z jego szczególnym, osobowym odniesieniem do Boga, które wyraża się poprzez właściwe tylko osobie zdolności do poszukiwania prawdy i dar wolności. W podejściu do osoby Kościół nie tylko wyraża swój stosunek do świata i jego problemów, ale także odnosi 
się do samego siebie. W takiej perspektywie sprawy świata i sprawy Kościoła nie jawią się jako tematy przeciwstawne, które konkurują ze sobą, czy nawet wzajemnie się wykluczają, ale stają się komplementarne w jedności. „Jeśli chodzi o Konstytucję duszpasterską Gaudium et spes - podsumowuje Wojtyła - to nie tylko ukazuje ona Kościół w jego stosunku do świata współczesnego, nie tylko więc ukazuje świat poprzez Kościół, ale zarazem ukazuje Kościół przez świat. Ukazuje Kościół skupiony nad każdą ważną i trudną sprawą człowieka - zwłaszcza nad tymi sprawami, które mają najszerszy zasięg w ludzkości - skupiony jako nad swoją własną sprawą” (Wojtyła 1967, 21).

\section{Moralne nauczanie Soboru}

Wśród propozycji, które napłynęły do Komisji Przedprzygotowawczej, były także takie, które odnosiły się wprost do zagadnień moralnych i samej teologii moralnej. Oscylowały one wokół dwu biegunów. Jedne głosy, pochodzące głównie ze środowisk rzymskich uczelni, postulowały skoncentrować się najpierw na obiektywnym porządku moralnym i przypomnieniu podstawowych zasad moralnych oraz natury normy i powinności moralnej. Inni, przede wszystkim biskupi z różnych Kościołów lokalnych, sugerowali podjęcie tematów związanych z rolą ludzkiej wolności i religijnych uwarunkowań w teologii moralnej, tak aby podkreślić pozytywne znaczenie chrześcijańskiej moralności, która nie sprowadza się tylko do przepisów prawa, ale realizuje się na drodze łaski poprzez sakramenty i cnoty, gdzie wolność człowieka jest aktywnie zaangażowana. Arcybiskup Wojtyła także nadesłał swoje uwagi, w których ,proponował naukę moralną zbudowaną na pojęciu osoby, świadomego i wolnego podmiotu działania" (Giertych 2004, 51; por. Skrzypczak 2011, 357-359).

\section{a) Od schematu De ordine morali christiano do konstytucji Gaudium et spes}

W efekcie prac przygotowawczych Komisja przedstawiła projekt, mający być podstawą dla prac soborowych, konstytucję dogmatyczną De ordine morali christiano, której autorami byli profesorowie rzymskich uczelni Franz Hürth SJ (Gregoriana), Louis Bertrand Gillon OP (Angelicum) i Ermenegildo Lio OFM (Antonianum). Zaproponowany schemat, który zawierał 86 punktów, z czego 28 dotyczyło potępienia różnych tez i doktryn, odpowiadał optyce pierwszej grupy respondentów, koncentrując się bardziej na zewnętrznym wymiarze teologii moralnej i nie uwzględniając wewnętrznych 
uwarunkowań człowieka. Był nadal bardziej legalistyczny niż teologiczny, opierał się bardziej na porządku prawnym niż porządku łaski, wynikającym z dziejozbawczej dynamiki, jaką niósł ze sobą porządek odkupienia. W trakcie dyskusji w Komisji Teologicznej projekt ten spotkał się z silną krytyką (swoje negatywne uwagi wyrazili m.in. B. Häring, P. Delhaye i R. Laurentin), jednak został przychylnie przyjęty przez kard. Alfreda Ottavianiego i został przesłany do Komisji Centralnej. Nie zakończyło to długiej historii redakcji tego schematu, gdyż mimo iż zgłaszano wobec niego liczne zastrzeżenia (m.in. kard. J. Döpfner i G.B. Montini), w lipcu 1962 roku został rozesłany ojcom soborowym. Mimo dalszych prac nad dokumentem, który zamierzano włączyć w szerszy tekst soborowy o odniesieniu Kościoła do dóbr tego świata, nazwanym Schematem XVII (De Ecclesiae principiis et actione ad bonum societatis promovendum), w którym zamierzano położyć większy akcent na powołanie człowieka do życia Bożego, i przesłania go w rok później do Komisji Koordynacyjnej, uważano go za wciąż niedopracowany. Wówczas ostatecznie zdecydowano, że moralne nauczanie Kościoła nie zostanie wyrażone w oddzielnym tematycznym dokumencie, ale będzie włączone w szersze nauczanie dotyczące relacji Kościoła do świata. Do tego zadania powołano nową komisję i tak zaczęły się prace nad późniejszą konstytucją Gaudium et spes, w której uwzględniono, chociaż w zupełnie nowym ujęciu, pewne fragmenty projektowanej konstytucji De ordine morali (por. Ratzinger 2016, 471-492). Pozostałe zaś zagadnienia włączono do innych tekstów soborowych ${ }^{9}$.

Owoc pracy tej Komisji, która składała się z teologów różnych specjalności ${ }^{10}$, był wypracowany na spotkaniu w belgijskim Malines we wrześniu 1963 roku, a później został jeszcze poprawiony przez oddzielną komisję złożoną z biskupów, którzy spotkali się w lipcu 1964 w Zurychu i ostatecznie, po renumeracji, stał się Schematem XIII pt. De Ecclesia in mundo huius temporis. W lipcu 1964 roku został przesłany ojcom soborowym, aby mógł być poddany dyskusji w czasie sesji październikowej. W dyskusję tę włączył się także abp Wojtyła, sugerując, by kwestie moralne były podawane nie tyle w moralizatorskim stylu, ile przez odwołanie się do argumentacji. Argumenty te powinny być zarówno natury racjonalnej, dlatego że Kościół chce trafić do wszystkich ludzi, ale także teologicznej, wszyscy bowiem wiedzą, że w doku-

${ }^{9}$ Odnajdujemy je na przykład w uchwalonym na pierwszej sesji obrad soborowych dekrecie Inter mirifica, gdzie jest mowa o obiektywnym porządku moralnym: „Sobór poucza, że wszyscy powinni bezwzględnie uznawać prymat obiektywnego porządku moralnego. Przewyższa on bowiem wszystkie inne porządki spraw ludzkich [...]. Właśnie porządek moralny, o ile tylko jest w całości i wiernie zachowywany, prowadzi człowieka do osiągnięcia pełnej doskonałości i szczęścia”, Dekret o środkach społecznego przekazu Inter mirifica, 6 .

${ }^{10}$ Do Komisji należeli: L. Cerfaux, G. Philips, A. Prignon, P. Delhaye, G. Thils, A. Dondeyne OP, Ch. Moeller, Y. Congar OP, K. Rahner SJ, B. Rigaux OFM, R. Tucci SJ. 
mencie tym przemawia Kościół. Sam też powołał w Krakowie oddzielną komisję teologów, którzy opracowali własny projekt ${ }^{11}$. „Doczesność została w nim ukazana jako niebędąca $w$ sprzeczności $z$ wiecznością, tak jak natura nie jest sprzeczna z nadnaturą. Wyjaśniając ten projekt, Wojtyła podkreślił, że nie tylko wola Boża jest u podłoża wszystkiego, ale również wolna wola człowieka, który dobrowolnie przylega do Kościoła. Spojrzenie zatem na miejsce człowieka w świecie i w Kościele może wychodzić od osoby ludzkiej” (Giertych 2004, 62). Jest tak dlatego, że w samej strukturze ludzkich władz, poznawczych i wolitywnych, zawarta jest wzajemna współzależność obiektywnego porządku moralnego i wolnego aktu człowieka, który ten porządek rozpoznaje i dobrowolnie wybiera. Szczególną rolę w tym rozpoznaniu odgrywa sumienie, któremu należy się poszanowanie zarówno ze strony Kościoła, jak i władzy świeckiej. Sumienie zachowuje swoją godność, nawet jeśli jest błędne, ale powinno być ono stale formowane i temu właśnie ma służyć nauczanie Kościoła. Między innymi pod wpływem polskiego projektu w konstytucji Gaudium et spes pojawił się obszerny wykład na temat osoby ludzkiej i jej godności.

Uwzględniając wszystkie uwagi zgłaszane przez ojców w dyskusji, a także polski projekt i jeszcze jedną propozycję zgłoszoną przez biskupów hiszpańskich, na posiedzeniu rozszerzonej Komisji Centralnej, która od 1 do 6 lutego 1965 roku obradowała w Ariccia pod Rzymem (udział w niej brał także abp Wojtyła), wypracowano tekst będący podstawą do ostatecznego rozpatrzenia na jesiennym zgromadzeniu plenarnym Soboru. Po dodaniu kilku poprawek dokument, którego początek wiązał się z pracą nad zagadnieniami moralnymi i dyskusją wokół ordine morali Kościoła, został ostatecznie uchwalony jako Konstytucja duszpasterska o Kościele w świecie współczesnym Gaudium et spes (por. Turbanti 2000).

\section{b) Zasadnicze linie moralnego wykładu Gaudium et spes}

Siedem lat po zakończeniu Soboru Karol Wojtyła (wówczas już kardynał) przedstawił studium nad realizacją Vaticanum II, które uważane jest za jedną z najlepszych analiz nauczania soborowego. W ocenie kard. Wojtyły zasadniczy zamiar, jaki przyświecał ojcom Soboru, można wyrazić w dwu pojęciach: pierwszym było kształtowanie świadomości, drugim zaś kształtowanie postaw. Tak też zatytułował dwie części swojego studium. Dodajmy, że pierwsza z nich dotyczyła podstawowego postulatu całego Soboru, którym było wzbogacenie wiary, druga - praktyki życia chrześcijańskiego i ma wymiar moralny.

${ }^{11}$ Do komisji tej należeli, oprócz arcybiskupa: ks. Andrzej Deskur, ks. Józef Majka, ks. Andrzej Bardecki, o. Jan Sieg SJ, o. Augustyn Jankowski OSB i o. Tadeusz Styczeń SDS. 
W nauczaniu Soboru całe życie moralne zasadza się w pierwszej kolejności na szczególnej więzi z Chrystusem. Wojtyła opisuje tę relację, używając pojęcia „uczestnictwa”. Jak je rozumieć? Otóż, życie chrześcijanina, w tym także życie moralne, jest świadectwem o Chrystusie nie na zasadzie czysto „zewnętrznej”, nawet nie tylko z wewnętrznym zaangażowaniem, co w naturalny sposób musi odpowiadać osobowemu działaniu, ale jest uczestnictwem w Chrystusie i w Jego misji, tzn. jest nie tyle własną aktywnością, ile jest współdzieleniem Jego misji, której Chrystus nadał ludzki wyraz w postaci troistej władzy: kapłana, proroka i króla. Wojtyła zwraca uwagę, że władzy tej nie należy rozumieć w kategorii ludzkiego rządzenia, ale jest to „po pierwsze «zadanie», o czym mówi łaciński termin munus (tria munera Christi), oraz po drugie «moc» albo «zdolność» do wypełnienia odnośnych zadań" (Wojtyła 1972, 92).

Spośród owej potrójnej władzy moralność chrześcijańska związana jest najbardziej z władzą królewską (munus regale). Powołując się na tekst Konstytucji o Kościele Lumen gentium, który mówi o „stanie królewskiej wolności” (Sobór Watykański II. 1964, 36), Wojtyła podkreśla, że polega on w pierwszej kolejności na pokonaniu w sobie panowania grzechu, jest samopanowaniem, które jest warunkiem realizacji drugiego zadania, jakim jest budowanie królestwa Bożego poprzez służenie Chrystusowi w bliźnich ${ }^{12}$. W ten sposób Wojtyła teologicznie, w najpełniejszym sensie tego pojęcia, ugruntowuje całą moralność chrześcijańską, w której nie chodzi tylko o etyczną poprawność ludzkiego działania, o to, aby ono było prawe, ale chodzi o głębszy wymiar, jakim jest uczestnictwo w misji zbawczej Chrystusa. „Postawa wynikająca $\mathrm{z}$ uczestnictwa $\mathrm{w}$ Chrystusowym munus regale staje się $\mathrm{w}$ świetle nauki Soboru szczególnym wyznacznikiem całej moralności chrześcijańskiej we właściwym dla niej odniesieniu do Chrystusa jako do najdoskonalszego wzoru" (Wojtyła 1972, 227) ${ }^{13}$.

W sposób najpełniejszy wyraża się to moralne nauczanie Soboru w Konstytucji Gaudium et spes, która omawia stosunek chrześcijanina do świata i wszystkich ważnych spraw, którymi on żyje. Można powiedzieć, że stała się swoistym podręcznikiem teologii moralnej, który stanowi konieczny punkt odniesienia dla każdej refleksji teologicznomoralnej, jaka jest podejmowana, co potwierdziła późniejsza praktyka pokazująca, że we wszystkich pracach

12 „Każdy chrześcijanin, który naśladując Chrystusa, zdobywa panowanie nad grzechem, a przez to urzeczywistnia właściwe osobie ludzkiej samo-panowanie, jakby rys królewskości - przez to także uczestniczy w Chrystusowym munus regale, a zarazem przyczynia się do urzeczywistnienia Królestwa Chrystusa" (Wojtyła 1972, 226).

${ }^{13}$ Por. także: „Moralność, wartość moralna, została w nauczaniu soborowym przedstawiona jako integralna część posłannictwa chrześcijańskiego. Przepajanie różnych dziedzin życia wartością moralną jest zarazem przepajaniem ich duchem Chrystusa" (Wojtyła 1972, 230). 
dotyczących zagadnień z teologii moralnej z pewnością pojawi się odniesienie do tego soborowego dokumentu ${ }^{14}$.

W wykładzie wstępnym Konstytucji, który omawia sytuację człowieka w świecie współczesnym, pojawia się kategoria „znaków czasu” (Sobór Watykański II 1965d, 4), wprowadzona już wcześniej do języka teologicznego przez Jana XXIII, który idąc za wezwaniem samego Jezusa (por. Mt 16,3), zachęcał do umacniania w Kościele nadziei wobec trudnych czasów (por. Jan XXIII 1961, 5-13). Niemniej jednak Sobór rozszerzył jej znaczenie, sprawiając, że stała się jedną z podstawowych kategorii teologicznych pozwalających na właściwe odczytanie relacji Kościoła ze światem. Kościół pragnie odczytać dziejowe przemiany zachodzące w świecie i określone sytuacje, które mają miejsce nie tylko w perspektywie socjologicznego opisu rzeczywistości, ale z punktu widzenia wiary. „Znakami czasu będą wszelkie fenomeny, które przez swoje ogólne właściwości i wielką częstotliwość charakteryzują daną epokę, i w których wyrażają się oczekiwania i dążenia żyjących ludzi" (Fiałkowski 2016, 29). Są one swoistym głosem objawiającego się wciąż Boga, który wzywa Kościół do zbawczego zaangażowania w życie ludzkości w tym, czym ona na co dzień żyje, i poprzez to, czym żyje. Wiąże się z tym umiejętność dostrzeżenia istotnych problemów człowieka, ich roztropnej oceny w świetle ewangelicznej prawdy i wypracowanie stosownej strategii apostolskiej działalności Kościoła.

Zasadniczy tekst Konstytucji składa się z dwu części. Pierwsza z nich (11-45) jest poświęcona człowiekowi i stanowi swoisty wykład antropologii integralnej, która traktuje o godności człowieka, jego miejscu we wspólnocie, a także w świecie oraz o jego ostatecznym powołaniu. Jest to problematyka, którą tradycyjnie podejmuje teologia moralna fundamentalna (natura człowieka, mądrość i rozum, wolność, sumienie, grzech, uświęcenie człowieka przez łaskę itd.). Gaudium et spes postrzega człowieka nie jako przedmiot zainteresowania teologii moralnej, ale jako świadomy i wolny podmiot w osobowej relacji z Bogiem, który jest jego Stwórcą, a dzięki sakramentalnemu włączeniu w Chrystusa staje się prawdziwie dzieckiem Bożym i uczestnikiem Bożego życia dzięki łasce, którą rozlewa w nim Duch Święty. Jako taki jest zdolny do dania odpowiedzi na Boże wezwanie i stawania się darem dla Boga i bliźniego w miłości. Ta personalistyczna wizja, istotnie związana $\mathrm{z}$ chrystologią, streszcza się bodaj w jednym zdaniu, które charakteryzuje chrześcijańską antropologię i stanowi inspirację dla teologii moralnej: „człowiek, będący na

${ }^{14}$ Papież Jan Paweł II niemal w każdym dokumencie, który wydał, a także prawie w każdym swoim wystąpieniu powołuje się na magisterium Soboru Watykańskiego II, a wśród nich bardzo często na Konstytucję Gaudium et spes. Także inne dokumenty posoborowego Magisterium często przywołują Konstytucję, np. w Katechizmie Kościoła katolickiego odwołań do tego dokumentu jest 167, najwięcej po Konstytucji Lumen gentium, których jest 297. 
ziemi jedynym stworzeniem, którego Bóg chciał ze względu na nie samo, nie może się w pełni odnaleźć inaczej, jak tylko przez szczery dar z siebie samego" (Sobór Watykański II 1965d, 24). Druga część (46-90) dotyczy ważniejszych problemów życia społecznego, które podzielone zostały na następujące dziedziny: małżeństwo i rodzinę, kulturę, życie gospodarczo-społeczne oraz życie wspólnoty politycznej.

Obie te części konstytucji kard. Wojtyła ujmuje syntetycznie, sprowadzając je również do określonych pojęć. Części pierwszej odpowiada pojęcie „tożsamości”, części drugiej pojęcie „solidarności”. Stanowią one klucz do odczytania zasadniczego przesłania moralnego Soboru. W nich zamyka się cała głębia jego nauczania.

Najpierw człowiek musi odkryć własną tożsamość, która funduje się na prawdzie o jego godności jako osoby ludzkiej, ale także jako stworzenia Bożego, odkupionego przez Chrystusa i powołanego do zjednoczenia z Bogiem w wieczności. Zarazem człowiek jest częścią wspólnoty, dzięki której staje się uczestnikiem całego dziedzictwa ludzkości, mającego wpływ na jego osobowe dojrzewanie, i z tego powodu jest zobowiązany troszczyć się o dobro tej wspólnoty. Ta troska wyraża się w pojęciu solidarności, która nie jest zwykłym współdzieleniem się z potrzebującymi, ale - jak stwierdza dekret o apostolstwie świeckich Apostolicam actuositatem - zasadza się na teologicznej prawdzie wcielenia Chrystusa, który stając się człowiekiem, utożsamił się z każdym z nas: „Sam bowiem przyjmując naturę ludzką, związał ze sobą całą ludzkość osobistą nadprzyrodzoną miłością i solidarnością w jedną rodzinę i jako znak rozpoznawczy swoich uczniów ustanowił miłość tymi słowami: «Po tym wszyscy poznają, żeście uczniami moimi, jeśli będziecie się wzajemnie miłowali» (J 13,35)" (Sobór Watykański II 1965a, 8). Ten właśnie tekst czyni Wojtyła podstawą do komentowania drugiej części Gaudium et spes, podkreślając, że ,przykazanie miłości stoi u podstaw całego porządku moralnego”, a Chrystus stanowi „w najszerszym zasięgu jakby nadprzyrodzone centrum ludzkiej solidarności" (Wojtyła 1972, 244).

Osią całego wykładu moralnego Konstytucji jest człowiek i jego ostateczne dobro, które w wymiarze doczesnym przejawia się w takim działaniu, aby wszystko, z czym człowiek spotyka się i co czyni na ziemi, stawało się bardziej ludzkie: „Według niemal zgodnej opinii wierzących i niewierzących wszystko, co jest na ziemi, powinno być odnoszone do człowieka, jako do jego centrum i punktu szczytowego wszelkiego istnienia" (Sobór Watykański II 1965d, 12). Ta podstawowa powinność moralna wyraża się w dwu wymiarach: indywidualnym i społecznym. „Jest to dążenie do realizacji godności osoby oraz prawdziwej wspólnoty pomiędzy ludźmi. Jedno i drugie łączy się najściślej z ewangelicznym porządkiem wartości oraz z całym chrześcijańskim etosem" (Wojtyła 1972, 241). 
Zgodnie ze swoją optyką pozytywnego wykładu, kiedy Sobór wskazywał na negatywne i niemoralne zjawiska w życiu społecznym, przedstawiał je przede wszystkim w perspektywie personalistycznej jako coś, co sprzeciwia się godności osoby ludzkiej i narusza jej fundamentalne prawa (por. Sobór Watykański II 1965d, 27). Formułując jasno swoją ocenę moralną, wyrażał to bardziej w kategoriach przestrogi niż zakazu. Podkreślając powszechną i niezbywalną godność ludzką, zachęcał do troski o to wszystko, co pozwala prowadzić wszystkim życie prawdziwie ludzkie (por. Sobór Watykański II 1965d, 26). Sobór unikał klasycznych formuł potępiających konkretne zachowania za wyjątkiem wojny, na której temat wielokrotnie wypowiadało się już Magisterium Kościoła ${ }^{15}$, chociaż wskazywał na pewne zjawiska, uznając je za niegodne i nieludzkie (np. totalitarne i dyktatorskie formy sprawowania władzy, nierówności społeczne powodujące nieludzkie warunki życia wielu osób). Nie wprowadził też żadnych szczegółowych rozstrzygnięć w kwestiach moralnych, choć noszono się z zamiarem odniesienia się do zagadnienia antykoncepcji i nawet podjęto pewne prace nad przygotowaniem stosownego dokumentu.

\section{c) Kwestie moralne w innych dokumentach Soboru}

Niejako ubocznym efektem dyskusji wokół zagadnień moralnych, z których zrodziła się Gaudium et spes, były także dwie kwestie, które zostały wyraźnie zaakcentowane w innych dokumentach soborowych.

Pierwszą była decyzja ojców, aby temat wolności religijnej wyłączyć z planowanego tekstu przyszłej Gaudium et spes, jak również nie umieszczać go - zgodnie z pierwotnym zamiarem - w dekrecie o ekumenizmie, lecz poświęcić mu oddzielny dokument w postaci deklaracji o wolności religijnej Dignitatis humanae (gruntownie przepracowanej przez amerykańskiego jezuitę J.C. Murraya, a ostatecznie zredagowanej przez abp. G.M. Garonne'a, późniejszego kardynała i przewodniczącego Papieskiej Rady ds. Kultury), która została uchwalona na ostatnim posiedzeniu plenarnym w 1965 roku razem z Konstytucją duszpasterską o Kościele w świecie współczesnym.

Deklaracja stwierdza, że prawo do wolności religijnej jest zakorzenione w godności osoby ludzkiej, która jest rozpoznawalna zarówno przez rozum

15 „Wszelkie działania wojenne, zmierzające bez żadnej różnicy do zniszczenia całych miast lub też większych połaci kraju z ich mieszkańcami, są zbrodnią przeciw Bogu i samemu człowiekowi, zasługującą na stanowcze i natychmiastowe potępienie" (Sobór Watykański II 1965d, 80). Niektórzy z ojców soborowych zgłaszali propozycje, aby umieścić także sformułowanie potępiające działania militarne związane z tzw. odstraszaniem nuklearnym i użyciem bomby atomowej. Jednak temat ten nie znalazł się w ostatecznym zapisie. 
ludzki, jak i na podstawie objawienia. $Z$ tego powodu „wszyscy ludzie powinni być wolni od przymusu ze strony czy to jednostki, czy to grup społecznych i wszelkiej władzy ludzkiej, i to przynajmniej tak, żeby nikt nie był zmuszany do działania wbrew swemu sumieniu" (Sobór Watykański II 1965c, 2). Aby jednak wolność religijna nie była rozumiana arbitralnie jako zupełna dowolność czysto subiektywnego wyboru, Sobór przypomina, że ta sama godność osoby ludzkiej, obdarzonej rozumem i wolną wolą, sprawia, że ludzie „są przynaglani i moralnie zobowiązani do poszukiwania prawdy przede wszystkim religijnej. Są też zobowiązani do przylgnięcia do poznanej prawdy oraz porządkowania całego swego życia według jej wymagań" (Sobór Watykański II 1965c, 2). Powinność ta staje się jeszcze bardziej widoczna, kiedy uwzględnimy, że „najwyższą normą życia ludzkiego jest prawo Boskie, wieczne, obiektywne i powszechne" (Sobór Watykański II 1965c, 3). I temu zagadnieniu Sobór poświęcił cały następny rozdział, czyniąc zadość oczekiwaniu ojców, aby prawu moralnemu przyznać należne miejsce wśród kwestii moralnych.

Drugą sprawą było nakreślenie wizji odnowy teologii moralnej, którą zawarto w dekrecie Optatam totius, stwierdzając, że powinna ona kierować się dwoma priorytetami (por. Sobór Watykański II 1965b, 16). Pierwszy stanowi głębsze studium Pisma Świętego, którym teologia moralna winna się karmić (doctrina S. Scripturae magis nutrita), czyli jego słowa nie tylko powinny przenikać wszystkie aspekty moralnego nauczania, ale powinno ono oddawać samego ducha Bożego i Jego wolę zawarte w objawionych tekstach. To soborowe wskazanie nie oznacza, że jedynie Pismo Święte jest autentycznym źródłem dla teologii moralnej. Należy ten tekst odczytywać w kontekście tego, co na temat objawienia mówi Konstytucja Dei verbum, która z Pismem Świętym ściśle łączy Tradycję i Urząd Magisterski Kościoła ${ }^{16}$. Wokół tych tematów toczyła się wśród ojców (i towarzyszących im teologów) ożywiona dyskusja. Pojawiały się bowiem głosy, że zasadniczym źródłem objawienia jest Pismo

${ }^{16}$ Konstytucja o Objawieniu Bożym Dei Verbum w numerze siódmym stwierdza, że Pismo Święte jest „źródłem wszelkiej zbawiennej prawdy i moralnego porządku”, które zostało przez apostołów przekazane ,głoszeniem ustnym, przykładami i zorganizowanym działaniem”, po nich zaś czynili to ustanowieni przez nich biskupi jako ich następcy. „Ta przeto święta Tradycja i Pismo Święte obydwu Testamentów są jakby zwierciadłem; w nim Kościół pielgrzymujący na ziemi kontempluje Boga". Istnieje zatem ścisła więź między Pismem Świętym i Tradycją, co potwierdza numer dziewiąty: „Święta Tradycja i Pismo Święte ściśle łączą się ze sobą i przenikają. Obydwa bowiem wypływają z tego samego Bożego źródła, zespalają się jakby w jedno i zmierzają do jednego celu". Natomiast strażnikiem i interpretatorem ich obu jest Urząd Nauczycielski Kościoła, który „nie jest ponad słowem Bożym, lecz jemu służy, nauczając jedynie tego, co zostało przekazane" (Sobór Watykański II. 1965, 10). Istnieje między nimi ścisła więź, do tego stopnia, że ,jedno bez pozostałych nie może istnieć, a wszystkie razem, każde na swój sposób, pod wpływem Ducha Świętego skutecznie przyczyniają się do zbawienia dusz", tamże. 
Święte, a jedyną drogą do odczytania jego treści jest metoda historyczno-krytyczna, a nie żywa wiara Kościoła, co mogłoby oznaczać, że Kościół nie powinien nauczać niczego, co nie byłoby przez ową metodę potwierdzone. „Według takiej teorii - wspomina J. Ratzinger - «wierzyć» oznaczałoby «sądzić», «myśleć», posiadać opinię podlegającą ciągłym rewizjom” (Ratzinger 2005, 105).

Poza tym, w refleksji moralnej należy także odwoływać się tradycyjnie do prawa naturalnego, czego wzór dał sam Sobór. Na przykład Konstytucja Gaudium et spes wielokrotnie odwołuje się do prawa zapisanego w sercu człowieka: „Człowiek bowiem ma w swym sercu wypisane przez Boga prawo, wobec którego posłuszeństwo stanowi o jego godności i według którego będzie sądzony" (Sobór Watykański II 1965d, 16), lub literalnie je przywołuje, kiedy kreśli moralne powinności życia społecznego (Sobór Watykański II 1965d, 89, także: $\mathrm{nr} 74,78,79)$.

Drugim priorytetem jest orientacja chrystologiczna moralnego nauczania, czyli podkreślanie w moralnym nauczaniu „wzniosłości powołania wiernych w Chrystusie" i przynoszenia owoców miłości. Ten drugi wymóg należy interpretować w kontekście innej nowatorskiej myśli Soboru, jaką jest nauczanie o powszechnym powołaniu do świętości. Życie moralne nie może być sprowadzone do pewnego minimum dobra, jakie człowiek winien realizować, co starała się określać dotychczasowa nauka moralna, zwłaszcza w kazuistycznej formie. Prawdziwe życie w Chrystusie nie może się sprowadzać jedynie do unikania grzechów i przestrzegania jasno określonych przykazań i prawa, lecz jest wezwaniem do upodobnienia się do Chrystusa, który w posłuszeństwie dla Ojca oddał całego siebie braciom, aż do największej ofiary na Krzyżu. Najpełniejszą treścią życia moralnego ucznia Chrystusa jest zatem świętość.

Sobór mówi o tym w Konstytucji Lumen gentium już w drugim rozdziale, który charakteryzuje naturę i misję Ludu Bożego. Wierni włączeni w ciało Chrystusa są uczestnikami Jego kapłańskiej misji, której natura aktualizuje się w sakramentach i cnotach. Obdarzeni tymi darami wszyscy chrześcijanie „we wszystkich sytuacjach życiowych i w każdym stanie powołani są przez Pana, każdy na właściwej sobie drodze, do doskonałej świętości, jak i sam Ojciec jest doskonały" (Sobór Watykański II 1964, 11). Konstytucja poświęciła również temu tematowi oddzielny, piąty rozdział. Powołanie do świętości wypływa z faktu wezwania Chrystusa, zawartego w słowach „Bądźcie więc wy doskonali, jak doskonały jest Ojciec wasz niebieski” (Mt 5,48), jak też z całego dzieła odkupienia, dzięki któremu chrześcijanie stali się prawdziwie dziećmi Bożymi i uczestnikami Bożej natury. „Dlatego - konkluduje Sobór - dla wszystkich jest jasne, że wierni każdego stanu i zawodu powołani są do pełni życia chrześcijańskiego oraz doskonałości miłości" (Sobór Watykański II 1964, 40). Drogą do świętości jest zaś wiara i czynne praktykowanie miłości. 
Wierni osiągną ją, ,jeśli z wiarą przyjmują wszystko z ręki niebieskiego Ojca i współdziałają z wolą Bożą, okazując także w służbie doczesnej wszystkim tę miłość, którą Bóg umiłował świat" (Sobór Watykański II 1964, 41). Dążenie to wspierają także różnorakie rady, których przestrzeganie zalecał swoim uczniom Chrystus, szczególnie zaś dar dziewictwa i celibatu, ubóstwa i posłuszeństwa. Mimo iż w Kościele od wieków istnieją trwałe formy praktykowania tych rad, to jednak są one darem i przeznaczeniem dla wszystkich. Tym samym Sobór koryguje wypracowany w teologii podział na tych wiernych, którzy zobowiązani są do zachowywania przykazań, i tych, którzy wznosząc się ponad to minimum, żyją według rad ewangelicznych jako należących do stanu doskonalszego.

Trzecią ważną kwestią, którą planowano włączyć w nauczanie soborowe, było zagadnienie odpowiedzialnego rodzicielstwa. Zostało ono już podjęte w pracach nad Schematem XIII w rozdziale dotyczącym małżeństwa i rodziny. Wyłoniły się wówczas dwa kierunki spojrzenia. Pierwszy, który na sali obrad soborowych przedstawił amerykański abp John Francis Dearden, podkreślał że rodzice są powołani do wielkodusznego i świadomego ojcostwa, a odpowiedzialną decyzję o liczbie dzieci powinni podejmować sami małżonkowie kierowani sumieniem i roztropnością. Druga propozycja, zreferowana przez kard. Ernesta Ruffiniego, wskazywała przede wszystkim na obiektywny porządek rzeczy i sakramentalny charakter chrześcijańskiego małżeństwa, z czego wynikają zobowiązania małżonków, których nie można relatywizować, tylko jasno i wyraźnie formułować.

Podczas prac komisji, odbywających się w domu ojców paulinów w Ariccii w Górach Albańskich, wypracowano także zarys problematyki dotyczącej małżeństwa i rodziny, która w harmonijny sposób traktowała o dwu dobrach małżeństwa, jakimi są wzajemna miłość i płodność, wiążąc kwestię odpowiedzialnego rodzicielstwa zarówno z sumieniem małżonków, jak też z obiektywnym prawem Bożym. Biskup Wojtyła, który brał udział w tych spotkaniach, wskazywał na ten właśnie moment jako najpełniej odpowiadający godności osoby ludzkiej: „Sobór uznaje, że różne powody, zarówno indywidualne, jak i społeczne, mogą wymagać regulacji poczęć, ale powinno się to odbywać w zgodzie z prawem moralnym, nie naruszając godności osoby ani czystości małżeńskiej” (Wojtyła 2014, 179).

Ostatecznie Sobór, uwzględniając wszystkie głosy, przyjął tekst, który podkreślał zarówno wagę miłości małżeńskiej, jak i zadanie przekazywania życia, które wypływa z owej miłości, na wzór Boga Stwórcy, który z miłości powołuje ludzi do istnienia. Przekazywanie życia jest własnym zadaniem małżonków, które powinni podejmować w duchu odpowiedzialności po wyrobieniu sobie roztropnego osądu co do praktycznej realizacji tego zadania. „Osąd taki małżonkowie winni wyrobić sobie sami, w obliczu Boga”. Jednakże - na 
co dalej wskazuje tekst soborowy - „w sposobie postępowania małżonkowie chrześcijańscy niech będą świadomi tego, że nie mogą działać jedynie według własnego uznania, lecz zawsze powinni kierować się sumieniem zgodnym z prawem Bożym, posłuszni Nauczycielskiemu Urzędowi Kościoła, który interpretuje je w świetle Ewangelii" (Sobór Watykański II 1965d, 50). W następnym punkcie Konstytucji, który podkreśla konieczność harmonijnego łączenia miłości małżeńskiej z powinnością poszanowania życia, ojcowie soborowi przyznają, że może zaistnieć sytuacja, iż w pewnych okolicznościach współczesnego życia ,liczba potomstwa, przynajmniej przez pewien czas, nie może się zwiększyć", to jednak nie usprawiedliwia działań, które są niezgodne z prawem Bożym, szczególnie tych, które zagrażają życiu dziecka. „Są tacy, którzy mają odwagę proponować niegodziwe rozwiązania tego rodzaju problemów, a nawet nie cofają się przed zabójstwem. Kościół jednak przypomina, że nie może być rzeczywistej sprzeczności pomiędzy Boskimi prawami przekazywania życia a pielęgnowaniem prawdziwej miłości małżeńskiej”. Natomiast - dodaje - ,aborcja i dzieciobójstwo są haniebnymi przestępstwami” (Sobór Watykański II 1965d, 51).

Omawiając te tematy, Sobór nie wspomina o antykoncepcji. W przypisie do tego fragmentu zaznaczono, że pewne kwestie, które „wymagają innych, jeszcze wnikliwszych badań", zostały na polecenie ojca świętego przekazane Komisji ds. Zaludnienia, Rodziny i Rozrodczości, tak aby na podstawie ich prac papież mógł wydać orzeczenie, wobec czego w tym miejscu Sobór „nie zamierza bezpośrednio przedkładać konkretnych rozwiązań”. Jednocześnie przypis ten wskazuje na trzy wypowiedzi Magisterium. Pierwsza dotyczy encykliki Piusa XI Casti connubii, w której papież wyraźnie i jednoznacznie potępił działania w dziedzinie prokreacji, które zmierzają do tego, by „wystrzegać się go starannie, nie przez uczciwą wstrzemięźliwość [...], lecz gwałceniem aktu naturalnego" (Pius XI 1930, 539-592). Ponieważ, jak stwierdza papież, w dzisiejszych czasach takie poglądy są coraz jawniej głoszone, wobec tego obwieszcza: „Ktokolwiek użyje małżeństwa w ten sposób, by umyślnie udaremnić naturalną siłę rozrodczą, łamie prawo Boże oraz prawo przyrodzone i obciąża sumienie swoje grzechem ciężkim" (Pius XI 1930, II, 1ª). Papież potępia także działania aborcyjne, niezależnie od tego czy są one kierowane wskazaniem lekarskim, czy z przyczyn społecznych lub eugenicznych (por. Pius XI 1930, I, 1b).

Drugą wypowiedzią jest przemówienie Piusa XII do położnych, w którym papież porusza trzy zasadnicze kwestie: przypomina o nienaruszalności życia ludzkiego, niezależnie od jakichkolwiek przyczyn, o niegodziwości działań zmierzających do uniemożliwienia poczęcia dziecka oraz o niegodziwości sztucznego zapłodnienia (por. Pius XII 1951, 835-854). Trzecim dokumentem jest przemówienie Pawła VI do kolegium kardynałów, w którym podsumował 
wydarzenia pierwszego roku swego pontyfikatu, a także nakreślił zadania, jakie należy podjąć, w tym między innymi kwestię regulacji urodzin i związane z nim zagadnienie moralności życia małżeńskiego. Papież stwierdził, że Kościół dostrzega w tej dziedzinie wielorakie kompetencje małżonków, ale także swoją własną powinność i obowiązek rozpatrzenia tego problemu w świetle prawa Bożego. Dlatego zagadnienie to ,zostało poddane refleksji w sposób najbardziej szeroki i głęboki jak to tylko możliwe, jak tego wymaga tak ważna materia". Papież wyraził też nadzieję, że niebawem będzie mógł przedstawić wyniki tych prac w sposób najbardziej odpowiedni, do tego jednak czasu - zaznaczył - nie mamy wystarczającego powodu sądzić, jakoby nauczanie, które w tej kwestii sformułował Pius XII, straciło swą ważność i z tego powodu przestało obowiązywać (,superate e perciò non obbliganti”), przeciwnie, należy je zachować w całej pełni (Paweł VI 1964, 589).

W trzy lata po zakończeniu Soboru problematyka ta stanie się tematem encykliki Pawła VI Humanae vitae.

Kwestią podobnie gorąco dyskutowaną był temat celibatu. Już w ramach prac nad dekretem o posłudze kapłanów zastanawiano się nad podjęciem tematu celibatu, skoro Sobór powrócił do starożytnej tradycji diakonatu żonatych, o czym jest mowa w Konstytucji Lumen gentium. Papież jednak, w obawie przed nadmierną dyskusją, a nawet sporami, które mogłyby się przeciągać, poprosił ojców soborowych przez pośrednictwo dziekana kolegium kardynalskiego kard. Eugène'a Tisseranta, aby odłożono ten temat i pozostawiono go do jego osobistego rozstrzygnięcia, tak aby móc zakończyć Sobór 8 grudnia, w tym samym dniu kiedy w 1959 roku zostało ogłoszone jego zwołanie (Paweł VI 1965, 898-899). W efekcie kwestia celibatu nie była dyskutowana, a w 1967 roku Paweł VI ogłosił encyklikę Sacerdotalis coelibatus, w której potwierdził istniejącą w Kościele Rzymskim tradycję święcenia kapłanów spośród osób bezżennych (Paweł VI 1967, 657-697).

\section{Zakończenie}

Wszyscy uczestnicy Soboru mieli wewnętrzne przekonanie, że uczestniczą w wielkim wydarzeniu życia Kościoła i nie chodziło jedynie o aspekt ceremonialno-organizacyjny, ale o doświadczenie nowego wylania Ducha Świętego, sprawiającego, że Sobór stał się „wielkim darem dla Kościoła, dla wszystkich, którzy w nim uczestniczyli, jest darem dla całej rodziny ludzkiej, darem dla każdego z nas" (Jan Paweł II 1994, 123). W parze z tym doświadczeniem, poniekąd nawet jako jego konsekwencja, idzie przekonanie, że Sobór wciąż pozostaje do odkrycia, wciąż wymaga głębszego zrozumienia, a przede wszystkim wcielania w życie. Podstawą jest jednak jego właściwe odczyta- 
nie, niezanieczyszczone uproszczeniami, powierzchownymi interpretacjami czy wręcz instrumentalnym wykorzystaniem jego nauki. „Zachodzi potrzeba stwierdził Jan Paweł II - mówienia o Soborze, ażeby go interpretować w sposób właściwy, a bronić przed interpretacjami tendencyjnymi. Takie interpretacje bowiem istnieją, nie pojawiły się dopiero po Soborze, w pewnym sensie Sobór zastał je już w świecie, a nawet w Kościele, jako pewne dyspozycje albo antydyspozycje do jego przyjęcia i zrozumienia, a także wprowadzania w życie" (Jan Paweł II 1994, 123).

Niewątpliwie, nauczanie soborowe wymagało roztropnej i cierpliwej asymilacji w życie Kościoła, począwszy od Kościołów lokalnych, poprzez różne wspólnoty kościelne, a także środowiska teologiczne, w tym również moralistów. Asymilacja ta czasem przebiegała zbyt szybko i powierzchownie, wskutek czego wyraźnie zaczęły konkurować ze sobą dwa stanowiska.

Pierwsze wyrażało pewien niedosyt wobec reform zaproponowanych przez Sobór, który - zdaniem pewnych teologów i świeckich - zatrzymał się jakby w połowie drogi, a na wiele pytań nie udzielił wystarczającej odpowiedzi. Rodziło to przekonanie o swoistej bezsilności teologii i nauczania Kościoła wobec współczesnych wyzwań, wzmocnione jeszcze klimatem epoki, zafascynowanej coraz bardziej naukowym duchem i zaufaniem w postęp. Owocem takiej postawy była pokusa znajdywania rozwiązań podyktowanych indywidualnym sumieniem, zgodnie z potrzebą chwili. Zaczęły pojawiać się grupy księży i świeckich, którzy powołując się na kolegialną odpowiedzialność w Kościele (w nawiązaniu do soborowej kolegialności), wypracowywały własny styl duszpasterstwa. Do tego dochodził jeszcze kryzys wśród duchowieństwa, które poczuło się jakby zagrożone w swojej własnej tożsamości i misji przez soborowe nauczanie na temat powszechnego kapłaństwa i wezwanie świeckich do czynnej odpowiedzialności za apostolstwo. Zarazem mocno odczuwało ono presję ze strony coraz bardziej laicyzującego się świata, który nie rozumiał ich języka, a nowe problemy zamierzał rozwiązywać na swój własny sposób. Skutkiem tego wielu księży stawiało sobie pytanie, czy są jeszcze potrzebni. W rezultacie wzrosła liczba odejść z kapłaństwa księży diecezjalnych i zakonnych, a także wyraźnie zaczęła spadać liczba powołań.

Drugie stanowisko, przeciwnie, było zdania, że Sobór naruszył trwałe fundamenty wiary i dyscypliny kościelnej, zmodyfikował czy nawet radykalnie zmienił tradycyjne nauczanie i formy życia religijnego. Jacques Maritain w głośnej książce Wieśniak z Garonny (1966) wyraził swoje krytyczne uwagi po adresem niektórych idei soborowych: krytykował teologów za odejście od tomizmu, duchownych za popadanie w modernizm, a chrześcijan za to, że dają się oczarować socjologii i psychoanalizie. Inny katolicki filozof i etyk Dietrich von Hildebrand w książce powstałej dwa lata po Soborze Koń trojański w mieście Boga (1967) piętnuje modernistyczne nadużycia w Kościele. Swój nie- 
pokój wyraża także Louis Bouyer w pracy La décomposition du catholicisme (1968), krytykując zarówno progresistów, jak i tradycjonalistów.

Dylematy te nie ominęły także teologii moralnej, która wszakże już w okresie przedsoborowym dostrzegała konieczność głębokiej przemiany nie tylko w wymiarze czysto metodologicznym, ale także w ujęciu poszczególnych tematów, tak aby odpowiadały one nowemu humanizmowi czasów współczesnych. Inspirując się personalistyczną ideą dialogu ze światem, którą kierował się Sobór, podejmuje się w coraz większym stopniu współpracę z naukami o człowieku i naukami społecznymi, aby z jednej strony znaleźć bardziej adekwatną odpowiedź na problemy współczesnego człowieka, a z drugiej, aby podawana argumentacja moralna była bardziej zrozumiała. Zdecydowanie bardziej podkreśla się także rolę wolności, w przeciwieństwie do kazuistycznego wykładu poprzednich epok. Zamiast kierować się posłuszeństwem wobec zespołu norm, które postrzegano jako abstrakcyjne prawo, postuluje się drogę wolnej i odpowiedzialnej odpowiedzi, będącej wyrazem miłości wobec osoby Chrystusa, który stawia przed człowiekiem moralne wyzwania. Czasem to podkreślanie wolności przybierało tak mocny charakter, że przyznawano jej niemal absolutną wartość, do tego stopnia że to ona sama miałaby decydować o wartości moralnej czynów ludzkich. Na to niebezpieczeństwo zwróci później uwagę encyklika Jana Pawła II Veritatis splendor (1993).

Pojawiające się podręczniki dążą do skoncentrowania swojego wykładu wobec pewnych idei wiążących, które mają zdecydowanie personalistyczny charakter. Należą do nich takie kategorie jak: idea królestwa Bożego, odpowiedź na wezwanie Boże, idea powołania czy tajemnica Kościoła. Inni zaś rezygnowali z klasycznej formy podręczników, koncentrując się na opracowywaniu problemów szczegółowych, które pojawiały się wraz z coraz bardziej dynamicznie rozwijającym się życiem społecznym. Inspiracją takich pogłębionych studiów były często teksty magisterialnego nauczania kolejnych papieży: Pawła VI, Jana Pawła II i Franciszka, którzy podejmowali tematy o wyraźnie moralnym charakterze, jak: sprawa pokoju, godność ludzkiej pracy, rodzina, godność kobiety, sprawowanie sakramentu pokuty, rola świeckich w Kościele i świecie, kwestie stosunku sumienia do prawa moralnego, świętowanie niedzieli, kwestie starości i cierpienia, miłosierdzie, szacunek do stworzonego świata, braterstwo między ludźmi.

Na koniec trzeba jeszcze wspomnieć o dwu owocach Soboru, które pozostają ważne dla teologii moralnej. Pierwszym jest Kodeks prawa kanonicznego, promulgowany konstytucją apostolską Sacrae disciplinae leges 25 stycznia 1983 roku. Jak stwierdza konstytucja: ,,celem Kodeksu nie jest bynajmniej zastąpienie w życiu Kościoła lub wiernych wiary, łaski, charyzmatów a zwłaszcza miłości. Przeciwnie, w Kodeksie chodzi raczej o to, aby rodził taki porządek społeczności kościelnej, który - przyznając główne miejsce miłości, łasce 
i charyzmatom - jednocześnie ułatwiałby ich uporządkowany postęp w życiu czy to w społeczności kościelnej, czy to poszczególnych ludzi, którzy do niej należą" (Jan Paweł II 1983, s. VII-XIV, Kodeks prawa kanonicznego 1984, 11-13). Jako taki Kodeks jest stałym punktem odniesienia dla teologii moralnej, która opierając się na jego postanowieniach określających reguły i normy działania, twórczo je rozwija i interpretuje.

Drugim owocem jest Katechizm Kościoła katolickiego, którego powstanie było inicjatywą Soboru. W nim - jak stwierdził Jan Paweł II - ,całe bogactwo nauki Kościoła po Soborze Watykańskim II otrzymało nową syntezę i nowe niejako ukierunkowanie" (Jan Paweł II 1994, 127). Katechizm poświęca zagadnieniom moralnym trzecią część zatytułowaną Życie w Chrystusie (na ten temat zob. Życie w Chrystusie 1995). Już sam tytuł tej części wskazuje na biblijne, a zarazem personalistyczne ujęcie całego wykładu chrześcijańskiej moralności, co było postulatem pojawiającym się w przedsoborowej refleksji teologów moralistów, a zostało potwierdzone w nauczaniu Vaticanum II. Część tę Katechizm rozpoczyna od wskazania na godność człowieka stworzonego na obraz Boga, odkupionego przez Chrystusa i wezwanego do szczęścia w wiecznej komunii z Bogiem. Życie moralne jest wolną odpowiedzią człowieka na otrzymane dary i wezwanie Boga. Odpowiedź ta realizuje się w Chrystusie, który zarazem poucza i uzdalnia przez swoją łaskę do dania właściwej odpowiedzi.

\section{PERSONALISTIC APPROACH TO CHRISTIAN MORAL TEACHING IN THE MAGISTERIUM OF THE SECOND VATICAN COUNCIL}

\section{SUMMARY}

In the period preceding the Second Vatican Council, several projects were prepared, which for the Council Fathers were to be the basis for the discussions during plenary sessions. They included fundamental theological and pastoral problems which the Pre-Preparation Commission (Commissio antepreparatoria) considered the most important. Among the submitted proposals were also projects on moral issues: De ordine morali christiano and De castitate, matrimonio, familia et virginitate. Although they were well prepared in terms of content, they met with considerable criticism from members of the Theological Commission and some bishops, because in their opinion they did not correspond to the pastoral character of the Council, expected by Pope John XXIII. These projects were edited many times until it was finally decided that these issues would be addressed in a broader document discussing the relationship of the Church with the world, which eventually took the shape of a Pastoral Constitution on the Church in the modern world Gaudium et Spes. 
The axis of the entire teaching of this Constitution is the integral vision of the human person, created by God as a rational and free being, redeemed by Christ and called to an eternal community in God. Years later, Cardinal Karol Wojtyła commenting on the Constitution, synthesized its teaching, especially in moral matters, in two personalistic categories: "participation" and "solidarity". The first refers to the personal relationship of man with God, while the second characterizes the relationships of man toward the world formed by other people and communities in which they live. Both categories express man's personal commitment as a response to the gift and call contained in God's revelation to man.

Keywords: moral theology; personalism; history of Council Vatican II; dignity of human person; John XXIII; Paul VI; John Paul II

Słowa kluczowe: teologia moralna; personalizm; historia Soboru Watykańskiego II; godność osoby ludzkiej; Jan XXIII; Paweł VI; Jan Paweł II

\section{BIBLIOGRAFIA}

Acta synodalia Sacrosancti Concilii Oecumenico Vaticani II, t. 1-25. 1960-1995. Typis Polyglottis Vaticanis.

Alberigo, Giuseppe. 2005. Krótka historia II Soboru Watykańskiego. Tłumaczenie Paweł Borkowski. Warszawa: Instytut Wydawniczy Pax.

Atlas historyczny Soboru Watykańskiego II, red. Alberto Melloni, tłum. Paweł Borkowski. 2015. Warszawa: Instytut Wydawniczy Pax.

Bouyer, Louis. 1968. La décomposition du catholicisme. Paris: Aubier-Montaingne.

Fiałkowski, Marek. 2016. Inspiracje Konstytucji duszpasterskiej o Kościele w świecie współczesnym dla teologii znaków czasu. Roczniki Teologiczne 63, 27-34.

Forget, Jacques. 1906. Conciles. W: Dictionnaire de Théologie Catholique, red. Alferd Vacant, Eugéne Mangeot, Paris, kol. 636-676.

Giertych, Wojciech. 2004. Rachunek sumienia teologii moralnej. Kraków: Wydaw. M.

Hildebrand, von Dietrich. 2000. Koń trojański w mieście Boga. Przyczyny kryzysu w Kościele katolickim. Tłumaczenie Jerzy Wocial. Warszawa: S.K. Fronda.

Jan XXIII. 1959a. Allocuzione con la quale il Sommo Pontefice annuncia il Sinodo Romano, il Concilio Ecumenico e l'aggiornamento del Codice di Diritto Canonico.

Jan XXIII. 1959b. Encyklika „Ad Petri Cathedram”.

Jan XXIII. 1961. Konstytucja apostolska „Humanae salutis”.

Jan XXIII. 1962. Allocutio Ioannis pp. XXIII in sollemni ss. Concilii inauguratione.

Jan Paweł II. 1978. Pierwsze orędzie radiowe i telewizyjne , Urbi et Orbi”.

Jan Paweł II. 1983. Konstytucja apostolska ,, Sacrae disciplinae leges”.

Jan Paweł II. 1988. Motu propio „Ecclesia Dei”.

Jan Paweł II. 1992. Konstytucja apostolska „Fidei depositum”.

Jan Paweł II. 1993. Encyklika "Veritatis splendor".

Jan Paweł II. 1994. Przekroczyć próg nadziei. Lublin: Redakcja Wydawnictw Katolickiego Uniwersytetu Lubelskiego.

Katechizm Kościoła katolickiego. 1994. Poznań: Pallottinum.

Kodeks prawa kanonicznego. Komentarz, red. P. Majer. 2011. Kraków.

Kompendium Katechizmu Kościoła Katolickiego. 2005. Kielce: Wydawnictwo Jedność. 
Maritain, Jacques. 2017. Wieśniak znad Garonny. Tłumaczenie Arkadiusz Ziernicki. Poznań: W drodze.

Paweł VI. 1964. Przemówienie do Kolegium Kardynałów z okazji pierwszej rocznicy swojego wyboru.

Paweł VI. 1965a. List apostolski „Ambulate in dilectione”.

Paweł VI. 1965b. List do kard. E. Tisseranrt.

Paweł VI. 1965c. Motu proprio „Integrare servandae”. Sacrae Congregationis S. Officii nomen et ordo immutantur.

Paweł VI. 1967. Encyklika ,, Sacerdotalis coelibatus".

Pius IX. 1870. List apostolski „Postquam Dei munere”.

Pius XI. 1922. Encyklika ,Ubi arcano”.

Pius XI. 1930. Encyklika „Casti connubii”.

Pius XII. 1951. Przemówienie podczas Kongresu Włoskich Położnych.

Ratzinger, Joseph. 1997. Sól ziemi. Chrześcijaństwo o Kościót katolicki na przelomie tysiacleci. Z kardynałem rozmawia Peter Seewald. Tłumaczenie Grzegorz Sowiński. Kraków: Znak.

Ratzinger, Joseph. 2005. Moje życie. Autobiografia Benedykta XVI. Częstochowa: Edycja Świętego Pawła.

Ratzinger, Joseph. 2016. Opera omnia, t. VII/1: O nauczaniu Soboru Watykańskiego II. Tłumaczenie Wiesław Szymona. Lublin: Wydawnictwo KUL.

Sobór Watykański II. 1964. Konstytucja dogmatyczna o Kościele „Lumen gentium”.

Sobór Watykański II. 1965. Konstytucja dogmatyczna o Objawieniu Bożym „Dei Verbum”.

Sobór Watykański II. 1965a. Dekret o apostolstwie świeckich ",Apostolicam actuositatem”.

Sobór Watykański II. 1965b. Dekret o formacji kapłanów „, Optatam totius”.

Sobór Watykański II. 1965c. Deklaracja o wolności religijnej „,Dignitatis humanae”.

Sobór Watykański II. 1965d. Konstytucja duszpasterska o Kościele w świecie wspótczesnym „, Gaudium et spes".

Skrzypczak, Robert. 2011. Karol Wojtyła na Soborze Watykańskim II. Zbiór wystapień. Tłumaczenie Michał T. Szczepański, Michał Romanek. Warszawa: Wydawnictwo AA sc.

Storia del concilio Vaticano II, t. 1-5, red. Giuseppe Alberigo. 1995-1999. Bologna: Società editrice il Mulino.

Synopsa tekstów Soboru Watykańskiego II, red. Tomasz Bielski. 1970. Poznań-Warszawa: Pallottinum.

Turbanti, Giovanni. 2000. Un concilio per il mondo moderno. La redazione della constituzione pastorale «Gaudium et spes» del Vaticano II, Bologna: Società editrice il Mulino.

Wojtyła, Karol. 1972. U podstaw odnowy. Studium o realizacji Vaticanum II. Kraków: Polskie Towarzystwo Teologiczne.

Wojtyła, Karol. 2014. Vaticanum II: czas twórczego myślenia. Wypowiedzi soborowe, red. A. Dobrzyński. Rzym: Ośrodek Dokumentacji i Studium Pontyfikatu.

Wojtyła, Karol. 1967. Wstęp ogólny. W: Sobór Watykański II. Konstytucje, dekrety, deklaracje. Poznań: Pallottinum, 9-23.

Życie w Chrystusie. Refleksje nad nauczaniem Katechizmu. Materiaty ze zjazdu moralistów, Konstancin-Jeziorna 29-30 maja 1995. 1995. red. Alojzy Marcol, Piotr Morciniec, Opole: Wydaw. św. Krzyża.

KRZYSZTOF GRYZ - ks. dr hab. nauk teologicznych w zakresie teologii moralnej, kapłan archidiecezji krakowskiej. W latach 1980-1986 studia na Papieskiej Akademii Teologicznej w Krakowie. Studia specjalistyczne z teologii moralnej na Uniwersytecie Nawarry w Pampelunie (1990-1994). Obecnie pracownik naukowy Uniwersytetu Papieskiego Jana Pawła II w Krakowie, kierownik Katedry Teologii Moralnej Ogólnej. Członek Stowarzyszenia Teologów Moralistów. 